Phinisi Integration Review
Vol. 2, No.2, Agustus 2019 Hal 174-184
Website: http://ojs.unm.ac.id/pir
p-ISSN: 2614-2325 dan e-ISSN: 2614-2317
DOI: https://doi.org/10.26858/pir.v2i2.9980

\title{
Pemenuhan Hak Pelayanan Kesehatan Bagi Masyarakat Di Rumah Sakit Lakipadada Kabupaten Tana Toraja
}

\author{
Alfionita Giovani Masau \\ Pendidikan Hukum dan Kewarganageraan, Universitas Negeri Makassar, Indonesia \\ Email: alfionitagiovani@gmail.com
}

\begin{abstract}
Abstrak. Penelitian ini bertujuan mengkaji tentang (i) Untuk mengetahui model pelayanan kesehatan yang dilakukan Rumah Sakit dalam pemenuhan hak pasien; (ii) Untuk mengetahui faktor-Faktor apa yang mempengaruhi pemenuhan hak pelayan kesehatan; (iii) Untuk mengetahui upayapemerintah dalam melakukan pemenuhan hak pelayanan kesehatan bagi masyarakat Penelitian ini menggunakan pendekatan kualitatif dengan teknik pengumpulan data melalui wawancara, kuisioner. Hasil Penetian menunjukkan bahwa (i) Model pelayanan kesehatan yang dilakukan Rumah Sakit Lakipadada Kabupaten Tana Toraja adalah pola atau kegiatan yang dilakukan di Rumah sakit dalam memberikan pelayanan kesehatan terhadap pasien, maka pelaksanaan model pelayanan kesehatan di Rumah Sakit Lakipadada kabupaten Tana Toraja didasarkan kepada Teori tentang Pelayanan kesehatan yang berkualitas dikembangkan Zeithalm dan Parasuraman yang digunakan juga sebagai landasan konsep penelitian yaitu dikenal dengan dimensi RATER meliputi aspek Reliability(realibilitas), Assurance (jaminan), Tangibles (tampilan/bukti fisik), Emphaty(empati), Responsiveness (ketanggapan dan kepedulian). (ii) faktor pendukung diantaranya sarana dan prasarana, tersedia tenaga medis, ketanggapan dan pengetahuan tenaga medis, serta memiliki Standar Operasional Prosedur yang lengkap, sedangkan penghambat meliputi sumber daya manusia, perbaikan gedung dan penambahan alat kesehatan, pasien yang dalam keadaan kurang labil. (iii) Peranan pemerintah melalui menyiapkan sarana prasarana yang memenuhi,menyiapkan tenaga ahli, terpenuhinya kesejateraan para tenaga kesehatan, mengadakan kegiatan pelatihan bagi tenaga medis, mengadakan bakti sosial bekerjasama dengan rumah sakit lakipadada di daerah terpencil 1 kali dalam sebulan.
\end{abstract}

Kata Kunci: Pemenuhan, Hak Pelayanan, dan Kesehatan

\begin{abstract}
Therefore, the problems that occur in this research are (i) What is the method used by the hospital to provide patient rights with proper health service? (ii) What kind of factors that affect the fulfillments of health service rights? (iii) What kind of effort that the government made to fulfill the rights of the people to get a proper health care service?. The purpose of this research is (i) To find out what kind of method use in the hospital to fulfill patients right towards a proper health service; (ii) to acknowledge what factors that affect the fulfillments of health service rights; (iii) and to understand the effort that the government has made to fulfill the rights of the people to receive a proper health care service. This research is done with a qualitative approach with interviewing and giving questionnaire as the way of collecting data. The result of this research shows that (i) The hospitals in Lakipadada, District of Tana Toraja, are using the basic theory of health services that guaranteed an excellent service with some noted aspects such as Rehability (Rehab), Assurance, Tangibles (Physical proof), Empathy, and Responsiveness (the way the staff response and shows empathy). (ii) Supporting factors
\end{abstract}


are facility and infrastructure, availability of medical personnel, how the personnel response and acknowledge medical issues, and a well thought operational procedure standard. Whereas the factors that inhibiting the hospital are the lack of human resource, needs of renovation, lacking of medical tools supply, and the condition of patient that is not stable. (iii) The government provides a proper facility and helping the infrastructure, they also provide some experts, fulfilling a proper salary for the medical personnel, doing a practice for the medical personnel, and exhibiting a social service by working together with the hospital of Lakipadada in an isolated area once a month.

Keywords: Fulfillment of Rights, Health Services, Citizens.

Ini adalah artikel dengan akses terbuka dibawah licenci CC BY-NC-4.0 (https://creativecommons.org/licenses/by-nc/4.0/ ).

\section{PENDAHULUAN}

Kesehatan adalah hak fundamental setiap manusia karena itu setiap individu, keluarga dan masyarakat berhak memperoleh perlindungan terhadap kesehatan.Konsepsi tanggung jawab negara dalam pemenuhan hak atas kesehatan merupakan implementasi yang harus dilakukan untuk memenuhi hak kesehatan warga negara.Pilar penegakan dan aspek terpenting hak asasi manusia (HAM) di bidang kesehatan bahwa setiap warga negara mempunyai kehidupan yang layak dan sehat.

Sebagaimana konvensi World Health Organization (WHO) 1948, telah menegaskan pula bahwa "Memperoleh derajat kesehatan yang setinggi-tingginya adalah suatu hak asasi bagi setiap orang" (the enjoyment of the highest. attainable standard of health is one of the fundamental rights of every human being). Istilah yang digunakan bukan "human rights", tetapi "fundamental rights", dalam terjemahkan Bahasa Indonesia menjadi "Hak hak Dasar".Bentuk Tanggung jawab Negara Dalam Pemenuhan Hak Atas Kesehatan Berdasarkan UUD Tahun 1945 Negara Republik Indonesia didalam pasal $28 \mathrm{H}$ dan Deklarasi Universal Hak Azasi Manusia oleh Perserikatan Bangsa Bangsa (PBB) Tahun 1948 (Indonesia ikut menandatanganinya) menetapkan bahwa Kesehatan adalah hak dasar setiap individu dan semua warga negara. Hak atas kesehatan ini bermakna bahwa pemerintah harus menciptakan kondisi yang memungkinkan setiap individu untuk hidup sehat, dan ini berarti pemerintah harus menyediakan sarana pelayanan kesehatan yang memadai dan pelayanan kesehatan yang terjangkau bagi semua kalanagan masyarakat.

Kesamaan memperoleh pelayanan adalah kesamaan jangkauan finansial ke pelayanan kesehatan adalah hak atas kesehatan diatur dalam UUD Tahun 1945 Negara Republik Indonesia, Pasal $28 \mathrm{H}$ ayat (1) "setiap orang berhak hidup sejahtera lahir dan batin, bertempat tinggal, dan mendapatkan lingkungan hidup yang baik dan sehat serta berhak memperoleh pelayanan kesehatan", Pasal $28 \mathrm{H}$ ayat (3) mengamanatkan bahwa "Setiap orang berhak atas jaminan sosial yang memungkinkan pengembangan dirinya secara utuh sebagai manusia yang bermartabat,Pasal 34 ayat (3) menandaskan bahwa "Negara bertanggung jawab atas penyediaan fasilitas pelayanan kesehatan dan pelayanan umum yang layak.

Mendapatkan layanan kesehatan adalah hak asasi manusia setiap warga negara Indonesia.Dalam UU No 36 tahun 2009 tentang Kesehatan, pasal 4 sampai pasal 8 menyatakan setiap orang berhak atas, kesehatan, akses atas sumber daya di bidang kesehatan, pelayanan kesehatan yang aman, bermutu, dan terjangkau. Layanan kesehatan merupakan juga ujung tombak dalam pembangunan kesehatan masyarakat, oleh karena itu Berdasarkan Undang-Undang Nomor 36 Tahun 2009 tentang Kesehatan pasal 3 "Pembangunan Kesehatan adalah upaya yang dilaksanakan oleh semua komponen bangsa yang bertujuan untuk meningkatkan kesadaran, kemauan, dan kemampuan hidup sehat bagi setiap orang agar terwujud derajat kesehatan masyarakat yang setinggi-tingginya". Selain itu, pembangunan kesehatan dapat sebagai investasi bagi pembangunan sumber daya manusia yang produktif secara sosial dan ekonomi. Pembangunan kesehatan dilaksanakan secara terarah, berkesinambungan dan realistis sesuai pentahapannya agar terwujudnya derajat kesehatan masyarakat. Pemerintah sebagai penyelenggara negara merupakan elemen utama dalam pelaksanaan dan penyelenggaraan 
pelayanan kesehatan kepada masyarakat yang bertujuan untuk meningkatkan taraf hidup dan kesejahteraan masyarakat.

Sistem pelayanan kesehatan adalah ujung tombak peningkatan derajat kesehatan, baik secara individu maupun masyarakat yang ada dimanapun, dan bagi mereka yang membutuhkannya. Sistem yang baik berdasarkan nilai dan norma yang ada dengan konsep dan kode etik masing-masing yang berlaku hampir di semua sektor kesehatan, tujuan utama demi perwujudan bagaimana setiap orang dapat hidup sehat, sejahtera, dan produktif. Persoalan kemudian ketika hal itu tidak sejalan dengan apa yang menjadi keinginan dan harapan setiap orang dalam mendapatkan pelayanan kesehatan yang mereka butuhkan diberbagai sektor kesehatan yang ada, baik pemerintah maupun swasta, hal ini tidak sejalan dengan cita-cita, visi dan misi serta tujuan baik secara eksplisit maupun implisit.

Gizi buruk, busung lapar,demam berdarah, difteri dan beberapa kasus yang terjadi di Indonesia mengenai pelayanan kesehatan di rumah sakit terhadap pasien yang kurang baik telah berdampak buruk terhadap citra rumah sakit dan tidak jarang akhirnya berujung pada proses hukum. Hal ini merupakan kurangmaksimalnya pelayanan kesehatan di Indonesia. Ini menjadi perhatian semua pihak baik pemerintah, rumah sakit, dan pihak - pihak terkait lainnya dalam pelaksanaannya.

Kasus -kasus yang pernah terjadi di Indonesia yaitu bayi empat bulan Tiara Debora yang dibawa ke UGD Mitra Keluarga Kalideres Debora meninggal sesudah rumah sakit menolak memasukkannya ke PICU (Pediatric Intensive Care Unit), begitu juga yang pernah terjadi Dera Nur Anggraini bayi malang, bayi Dera ditolak oleh 10 rumah sakit yang didatangi oleh ayah dan kakeknya. Tak kalah heboh adalah kasus Prita Mulyasari seorang ibu rumah tangga yang berhadapan dengan RS. Omni Internasional hingga ke meja hijau.Bayi Zahrah (bayi hidrocepalus) yang ditolak oleh rumah sakit Wahidin Sudiro Husodo Makassar dan kasus pelecahan terhadap pasien yang dilakukan oleh perawat di RS National Hospital Surabaya.

Selayaknya Pelayanan Kesehatan dalam penanganan yang ekstra cepat dan cerdas dari pemerintah dan masyarakat karena hak atas kesehatan masyarakat merupakan HAM maka seharusnya dilaksanakan paradigma pembangunan selain itu juga dalam bidang kesehatan juga menyiratkan hal yang sama pentingnya dilaksanakan, pada Pasal 32 ayat 1 UUK "Dalam keadaan darurat, fasilitas pelayanan kesehatan baik pemerintah maupun swasta wajib memberikan pelayanan kesehatan bagi penyelamatan nyawa pasien dan pencegahan kecacatan terlebih dahulu".

Bercermin dari aturan-aturan yang ada ini, seharusnya tidak ada lagi hal dan kejadian yang bertentangan dengan apa yang semestinya, hingga setiap orang akan merasakan segala bentuk pemberian pelayanan kesehatan yang baik. Akan tetapi pada kenyataan banyak kasuskasus yang menyebabkan kurang maksimalnya pelayanan kesehatan di RS.Seperti kasus Tiara Debora, Dera Nur Anggraini, Prita Mulyasari dan Zahrah.

Demikian pula locus yang di observasi awal menyangkut pelayanan kesehatan di RS Lakipada Kabupaten Tana Toraja, bahwa prosedur penerimaan dan pelayanan cenderung berbelit-belit, juga terhadap jadwal pelayanan di rumah sakit, kunjungan dokter yang tidak teratur sehingga pengetahuan petugas dalam menangani masalah/ keluhan pasien tidak memberikan informasi yang jelas tentang keadaan penyakit pasien (Hasil Observasi 12 Oktober 2015).

Berdasarkan uraian di atas maka dilakukan penelitian dengan judul "Pemenuhan Hak Pelayanan Kesehatan bagi masyarakat di Rumah Sakit Lakipadada Kabupaten Tana Toraja". Untuk menyamakan persepsi antara peneliti dengan pembaca maka fokus yang dikaji dalam penelitian ini dideskripsikan sebagai berikut: (1) Model pelayanan kesehatan yang dilakukan Rumah Sakit dalam Pemenuhan hak pasien. (2) Faktor-Faktor apa yang mempengaruhi pemenuhan hak pelayan kesehatan. (3) Upaya pemerintah dalam melakukan pemenuhan hak pelayanan kesehatan bagi masyarakat.

\section{METODE PENELITIAN}

Pada penelitian ini menggunakan metode penelitian deskriptif kualitatif. Penelitian ini dilakukan dengan mengamati subjek dan objek penelitian berdasarkan fakta-fakta yang ada. Fakta yang ditemukan dideskripsikan secara mendalam.Dalam penelitian ini, dimana peneliti menggambarkan secara kongkrit dan mendalam secara alami dilapangan sehingga memberikan pemahaman yang senyatanya artinya penelitian ini tidak dapat diwakilkan. Peneliti berperan serta dalam kegiatan yang dilakukan subjek 
penelitian, oleh karena itu peneliti menyatu dengan subjek penelitian agar mendapat informasi mengenai Pemenuhan Hak Pelayanan Kesehatan bagi Masyarakat di Rumah Sakit Lakipadada Kabupaten Tana Toraja.

Berdasarkan judul penelitian maka penulis memutuskan untuk menetapkan Rumah Sakit Lakipadada Kabupaten Tana Toraja sebagai lokasi penelitian.

Fokus penelitian ini adalah Model pelayanan kesehatan yang dilakukan Rumah Sakit dalam pemenuhan hak pasien, FaktorFaktor mempengaruhi pemenuhan hak pelayan kesehatan, Upaya pemerintah dalam melakukan pemenuhan hak pelayanan kesehatan bagi masyarakat.

Untuk mencapai pemahaman, maka fokus tersebut perlu dideskripsikan secara kongkrit, spesifik dan operasional sebagai berikut. Model Pelayanan yang dimaksudkan dalam penelitian ini adalah bentuk atau pola dalam memberikan pelayanan kesehatan di Rumah sakit Lakipadada Kabupaten Tana Toraja yang mengacu pada indikator. Pelaksanaan model pelayanan kesehatan di Rumah Sakit Lakipadada kabupaten Tana Toraja didasarkan pada model serqual (Service quality), teori untuk mengukur tentang pelayanan kesehatan berkualitas dikembangkan Zeithalm dan Parasuraman. Lima dimensi kualitas pelayanan Kesehatan yang mengacu pada Reliability (realibilitas), Assurance (jaminan), Tangibles (tampilan/bukti fisik), Emphaty (empati), Responsiveness (ketanggapan dan kepedulian).

Jenis dan Sumber Data Yang diugunakan adalah Data primer: Data yang diperoleh langsung dari Pasien yang berobat di Rumah Sakit Lakipadada kabupaten TanaToraja dan aparat yang bertugas di Rumah Sakit tersebut dalam hal ini bidang informan kepala Rumah Sakit, kepala bagian pelayanan kesehatan dan keperawatan, kepala bagian sarana dan prasarana, kepala bagian rekam medik, pasien dengan menggunakan teknik wawancara dan observasi. Kemudian Data berupa dokumendokumen, laporan-laporan penelitian, serta datadata dari Rumah Sakit Lakipada yang berkaitan dengan penelitian.

Sumber data utama dicatat melalui catatan tertulis dan pengambilan foto.Sumber data dalam penelitian adalah: Beberapa pasien, bidang informan kepala Rumah Sakit, kepala bagian pelayanan kesehatan dan keperawatan, kepala bagian sarana dan prasarana, kepala bagian rekam medik, di Rumah Sakit lakipada dalam memenuhi hak pelayanan kesehatan.dan Data yang diperoleh berupa buku-buku yang relevan, literatur- literatur dan sumber lainnya yang ada hubungan dengan masalah yang diteliti.

Instrumen utama dalam penelitian ini adalah peneliti, dimana peneliti berhubungan langsung dengan responden atau objek lainnya dalam mengumpulkan data serta mampu memahami kaitan kenyataan-kenyataan dilapangan. Oleh karena itu, peneliti juga berperan serta dalam melakukan pengamatan terhadap objek fokus penelitian.Sedangkan alat pengumpulan data penunjang adalah pedoman wawancara berupa daftar pertanyaan, catatan lapangan.

Teknik pengumpulan data menggunakan Observasi adalah kegiatan yang dilakukan oleh peneliti untuk mengamati kegiatan informan Kepala Rumah Sakit, Dokter, Bidan, Perawat dalam melakukan pelayanan kepada pasien. Dalam hal ini, untuk melakukan pengumpulan data peneliti menggunakan observasi terus terang kepada sumber data, bahwa ia sedang melakukan penelitian. Jadi informan akan mengetahui sejak awal sampai akhir tentang aktivitas peneliti. Sehingga peneliti akan turun langsung ke lokasi penelitian untuk mengambil data mengenai pelayanan kesehatan di Rumah Sakit Lakipadada Kabupaten TanaToraja.

Kedua Wawancara adalah kegiatan Tanya jawab secara langsung yang dilakukan peneliti kepada bidang informan kepala Rumah Sakit, kepala bagian pelayanan kesehatan dan keperawatan, kepala bagian sarana dan prasarana, kepala bagian rekam medik, dalam melakukan pelayanan kepada pasien yang bertugas dalam di Rumah Sakit Lakipadada Tana Toraja. Wawancara ini dilakukan agar mendapat jawaban dari permasalahan yang akan diteliti oleh peneliti, sehingga peneliti mengajukan beberapa daftar pertanyaan yang berhubungan dengan permasalahan yang akan diteliti kepada dan agar datanya lebih kuat peneliti juga melakukan wawancara bidang pelayanan kesehatan dan Asuhan keperawatan Rumah Sakit Lakipadada kabupaten Tana Toraja

Dokumentasi adalah cara pengumpulan data melalui penelusuran atau pencarian data dari catatan- catatan, buku-buku tentang pendapat, teori dan bukti. Maksudnya adalah dalam mendapatkan data-data dengan cara kepustakaan yaitu mengumpulkan, membaca dan mempelajari buku-buku (literature) yang 
ada hubungannya dengan masalah yang akan dibahas .Dokumentasi dalam penelitian ini bertujuan untuk memperoleh data melalui bidang informan kepala Rumah Sakit, kepala bagian pelayanan kesehatan dan keperawatan, kepala bagian sarana dan prasarana, kepala bagian rekam medik, pasien dalam melakukan pelayanan kepada pasien yang bertugas dalam di Rumah Sakit Lakipadada Tana Toraja

Analisis data merupakan bagian sangat penting dalam penelitian karena dari analisis ini akan diperoleh temuan, baik temuan subtantif maupun formal (Gunawan: 209). Pada hakikatnya, analisis data adalah sebuah kegiatan untuk mengatur, mengurutkan, mengelompokkan, member kode/tanda, dan mengategorikannya sehingga diperoleh suatu temuan berdasarkan fokus atau masalah yang ingin dijawab.

Adapun tahapan-tahapan yang digunakan peneliti dalam menganalisis data (Sugiono, 2010: 91), yaitu data reduction, data display, dan conclusion drawing/verification.

1. Data Reduction (Reduksi Data)

Mereduksi data berarti merangkum, memilih hal-hal yang pokok, memfokuskan pada hal-hal yang penting, dicari tema dan polanya (Sugiyono, 2010: 92).Dengan demikian data yang telah direduksi akanmemberikan gambaran yang lebih jelas dan mempermudah peneliti untuk melakukan pengumpulan data selanjutnya, dan mencarinya bila diperlukan.

2. Data Display (Penyajian Data)

Setelah data direduksi, maka langkah selanjutnya adalah mendisplaykan data.Dalam penelitian kualitatif, penyajian data bisa dilakukan dalam bentuk uaraian singkat, bagan, hubungan antar kategori, flowchart, dan sejenisnya.Yang paling sering digunakan untuk menyajikan data dalam penelitian kualitatif adalah dengan teks yang bersifat naratif. (Sugiyono, 2010: 95)

3. Conclusion Drawing/ Verification

Kesimpulan dalam penelitian kualitatif merupakan temuan baru yang sebelumnya belum pernah ada (Sugiyono, 2010: 99).Temuan dapat berupa deskripsi atau gambaran suatu obyek yang sebelumnya masih remang-remang atau gelap sehingga setelah diteliti menjadi jelas, dapat berupa hubungan kausal atau interaktif, hipotesis atau teori.

Pengecekan Keabsahan Data

Uji kredibilitas data atau kepercayaan terhadap data hasil penelitian kualitatif
(Sugiyono, 2010: 121) antara lain sebagai berikut :

Dengan perpanjangan pengamatan berarti peneliti kembali ke lapangan, melakukan pengamatan, wawancara lagi dengan sumber data yang pernah ditemui maupun yang baru (Sugiyono 2010: 122-123).Dengan perpanjanga $\mathrm{n}$ pengamatan ini, peneliti mengecek kembali apakah data yang telah diberikan selama ini merupakan data yang sudah benar atau tidak.

Trianggulasi dalam pengujian kredibilitas ini diartikan sebagai pengecekan data dari berbagai sumber dengan berbagai cara dan berbagai waktu (Sugiyonos 2010: 125). Peneliti melakukan trianggulasi dimana memeriksa keabsahan data untuk memastikan dan membandingkan informasi yang telah diberikan oleh informan utama dengan informasi yang diberikan oleh informan tambahan.

Yang dimaksud dengan bahan referensi di sini adalah adanya pendukung untuk membuktikan data yang telah ditemukan oleh peneliti (Sugiyono, 2010: 12-129).Data tentang interaksi manusia atau gambaran suatu keadaan perlu didukung oleh foto-foto, alat-alat bentuk perekam data penelitian kualitatif.Dalam laporan penelitian, sebaiknya data-data yang dikemukakan perlu dilengkapi dengan foto-foto atau dokumen autentik, sehingga menjadi lebih dapat dipercaya.

\section{HASIL DAN PEMBAHASAN}

\section{Model Pelayanan Kesehatan dalam Pemenuhan Hak Pasien di Rumah Sakit Lakipadada}

Model pelayanan kesehatan yang dimaksud adalah pola atau kegiatan yang dilakukan di rumah sakit dalam memberikan pelayanan kesehatan terhadap pasien, Kualitas pelayanan kesehatan merupakan hasil interaksi dari berbagai aspek, yaitu sistem pelayanan, sumber daya manusia pemberi pelayanan, strategi, dan masyarakat itu sendiri sehingga dapat dilihat secara konkrit,spesifik dan operasional dengan mengacu kepada teori Ziethalm dan Parasuraman, dengan indikator yang dapat dikaji adalah reliability (realibilitas), yaitu kemampuan untuk memberikan pelayanan yang sesuai dengan janji yang ditawarkan, ketetapan waktu layanan, ketetapan waktu pendaftaran di loket, ketetapan waktu pemeriksaan dokter, ketetapan dalam proses asuhan keperawatan, Lama waktu pemeriksaan dokter dan tenaga keperawatan. Assurance 
(jaminan) indikator penilaian, kemampuan dalam melakukan tindakan dengan cekatan medis dan keperawatan (mahir), keamanan selama perawatan (patient safety), keamanan barang bawaan pasien dan keluarga, penjelasan protocol asuhan keperawatan, pengetahuan tenaga medis dan perawatan. Tangibles (tampilan/ bukti fisik), indikator penilaian kemodernan fasilitas dan perlengkapan, kerapian tenaga medis dan keperawatan. kebersihan, keindahan, dan kerapian, kelengkapan fasilitas perawatan, kenyamanan dalam ruang perawatan, kenyamanan dan fasilitas ruang tunggu, Empati indikator penilaian, kemudahan dalam pengurusan administrasi, perhatian tenaga medis untuk bertanya keadaan dan perkembangan kondisi pasien setiap waktu (frekuensi vasitasi dokter), perhatian perawat untuk melihat kondisi pasien dan menanyakan keadaan pasien (frekuensi kunjungan petugas selama dirawat), kemudahan mendapatkan segala kebutuhan dan informasi, kemudahan dalam membayar biaya perawatan dan menebus obat, Responsiveness (ketanggapan dan kepedulian) indikator penilaian, ketanggapan tenaga medis terhadap keluhan atau masalah kesehatan pasien, keramahan dan kesopanan tenaga medis selama perawatan, kecepatan petugas dalam memberikan pelayanan saat dibutuhkan (kesiapsiagaan petugas).

ketanggapan semua petugas dalam merespons kebutuhan pasien dan keluarganya, ketepatan dalam pelayanan makan dan minuman selama perawatan.

\section{Faktor pendukung dan penghambat mempengaruhi pemenuhan hak pelayanan kesehatan di Rumah Sakit Lakipadada Kabupaten Tana Toraja}

\section{a. Faktor Pendukung}

Berdasarkan hasil Observasi dan wawancara maka faktor mendukung yang dihadapi tercapainya pemenuhan hak pelayanan kesehatan yang berkualitas ditandai dengan adanya sarana penunjang yaitu:

Adanya sarana dan prasarana sebagai penunjang terlaksananya pelayanan yang baik. sebagai Seksi Pelayanan dan Penunjang Medik, mengungkapkan dalam hasil temuan bahwa Salah satu faktor utama pelayanan kesehatan yang berkualitas terpenuhinya alat penunjang medis yang moderen yaitu Intensive care unit(ICU), Intensive cardiologi care unit(ICCU), Neonatal Intensive care unit(NICU), kamar
Operasi, Unit Transfusi darah (UTD), parkiran yang luas, dan ruang tunggu pasien, tempat konsultasi dokter atau ruang perawatan serta ruang inap yang bersih,nyaman, bebas dari polusi sehingga pasien puas terhadap pelayanan yang diberikan pihak Rumah sakit.

Disamping peralatan medis yang standar juga di dalam rumah sakit, obat merupakan sarana yang mutlak diperlukan, bagian farmasi bertanggung jawab atas pengawasan dan kualitas obat.Persediaan obat harus cukup, penyimpanan efektif, diperhatikan tanggal kadaluwarsanya.

Tersedia tenaga media. Suatu pelayanan akan berjalan dengan baik jika tersedianya tenaga medis yang yang memiliki kompeten pada bidangnya. Sebagaimanaseksi keperawatan mengungkapkanbahwa dalam menangani berbagai macam penyakit pasien di Rumah Sakit menyediakan Dokter spesialis, perawat, bidan dan tenaga medis lainnya yang bisa bekerja sesuai dengan bidangnya atau sesuai latar belakang pendidikannya sehingga pasien dapat mengetahui setiap penyakit yang diderita. Setiap pasien yang diberikan tindakan harus diketahui penyakit yang diderita dan diagnosis harus tepat melalui alternatif juga dibutuh tenaga ahli yang profesional dalam bidangnya untuk kesembuhan pada pasien.

\section{Empati dan Pengetahuan Tenaga Medis}

Kemampuan para tenaga medis dalam memberikan pelayanan kesehatan baik dan peduli terhadap keluhan setiap pasien dan memiliki pengetahuan dalam menjelaskan penyebab keluhan atau penyakit dari pasien tersebut. Sebagaimana Eliaser Toding Mendila sebagai bidang keperawatan mengungkapkan bahwa Pelayanan kesehatan yang dilakukan para dokter,bidan, perawat di Rumah sakit lakipadada bersifat paripurna yang menyangkut komprehensif mengenai upaya promotif, preventif,kuratif dan rehability dan holistik yang menyangkut mengenai aspek bio, psiko, sosial, dan spritual. Agar terwujudnya pelayanan kesehatan yang bersifat paripurna, para tenaga medis dalam melakukan pelayanan tersebut melalui rasa empati tercermin dalam perilaku tenaga medis, dan merupakan salah satu faktor mereka dalam menjalankan tugas pelayanannya yaitu keramahan dan kesabaran yang tujuannya adalah untuk meringankan beban pasien sehingga perasaan pasien jauh lebih baik dari sebelumnya. Tenaga medis dengan senyum, salam, sapa serta sopan santunnya bisa membangkitkan inisitaif pasien untuk sembuh, 
juga kemampuan tenaga medis dalam menjelaskan penyebab dari penyakit pasien, dan hal-hal apa yang selanjutnya pasien lakukan dalam memperoleh kesembuhan.

( wawancara 8 juni 2018, pukul 10.45).

\section{Memiliki Standar Operasional Prosedur Yang Lengkap}

Kualitas pelayanan rumah sakit akan lebih baik untuk memenuhi permintaan masyarakat akan pemenuhan hak pelayanan kesehatan yang sesuai dengan standar operasional Prosedur yang ada di Rumah Sakit. Sebagaimana Beatrix Marendeng sebagai Seksi Pelayanan danPenunjang Medik, , mengungkapkan bahwa dengan adanya Standar Operasional Prosedur ini menjadi pedoman dan langkah para tenaga medis dalam memberikan tindakan penyembuhan terhadap pasien dan perencanaan pengadaan sarana dan alat kesehatan yang disesuaikan dengan kebutuhan dan meningkatkan pemanfaatan secara optimal."( wawancara 6 juni 2018 pukul 12.30).

\section{Aspek Biaya}

a. Faktor pendukung terwujudnya pelayanan yang berkualitas adalah biaya pengobatan. Sebagaimana di ungkapkan seksi Keperawatan bapak Eliaser Toding Mendila, bahwa biaya pengobatan di RS Lakipadada relatif murah dibandingkan rumah sakit lain di Kabupaten Tana Toraja, Biaya pengobatan di RS Lakipadada terjangkau oleh masyarakat luas karena Rumah Sakit lakipadada ini merupakan rumah sakit milik pemerintah jadi dana menyangkut penyelengaraan pelayanan kesehatan dari anggaran pendapatan belanja daerah. Berdasarkan observasi 11 juni 2018, Pasien di RS Lakipada yang diambil 30 orang yang mewakili pasien berpendapat bahwa pasien tetap akan datang kembali ke RS Lakipada, dikarenakan biaya yang ditetapkan RSU Lakipada terjangkau bagi pasien. Rumah Sakit Umum (RSU) Lakipada adalah rumah sakit milik Pemerintah dan menjadi rujukandari kabupaten yang lain.

Peranan pemerintah melalui Program Jaminan Kesehatan Nasional yang bekerja sama dengan Badan Penyelenggaran Jaminan Sosial Kesehatan (BPJS Kesehatan) yang melayani kepesertaan dari pemegang Kartu ASKES/ JKNI, BPJS Ketenagakerjaan, Jasa Raharja serta Kepesertaan mandiri dan pihak swasta merupakan faktor-faktor yang dapat meningkatkan pelayanan kesehatan bagi masyarakat sebagai wujud pemenuhan hak pelayanan kesehatan bagi masyarakat sehingga dapat meningkatkan jumlah kunjungan pasien di rumah sakit.(wawancara 7 juni 2018, pukul 11.00).

\section{b. Faktor Penghambat}

Berdasarkan hasil Observasi dan wawancara maka faktor yang menghambat tercapainya pemenuhan hak pelayanan kesehatan yang berkualitas ditandai dengan adanya:

\section{Kurangnya Dokter Spesialis}

Rumah sakit sebagai suatu institusi pelayanan kesehatan masyarakat mempunyai sumber daya manusia (SDM) yang kualitasnya sangat berperan dalam pemenuhan hak pelayanan kesehatan bagi masyarakat, bahwa pelaksanaan pemenuhan hak pelayanan kesehatan oleh para tenaga medis diantaranya bidan perawat, dokter, terutama di rumah sakit lakipadada masih kekurangan dokter spesialis dipenyakit tertentu dan hal ini membuat pasien harus dirujuk ke Makassar untuk mendapatkan pengobatan, ( wawancara 8 juni 2018, pukul 10.45).

\section{Pembangunan gedung yang belum rampung dan penambahan alat kesehatan.}

Faktor penghambat dalam memberikan pelayanan kesehatan bagi masyarakat dengan adanya beberapa bangunan atau gedung tua.Sebagaimana diungkapkan Seksi Kesehatan Lingkungan, Sarana dan Prasarana bahwa dukungan terutama dari pemerintah setempat sangat di perlukan karena sarana dan prasarana dalam menghadirkan pelayanan kesehatan yang standar kepada masyarakat sangat diharapakan karena masih adanya beberapa gedung tua yang terpaksa masih digunakan diakibatkan karena pengguna jasa rumah sakit ini semakin meningkat. Dari data menunjukkan bahwa ada indikasi kunjungan pasien dari tahun ke tahun semakin meningkat.( Wawancara tanggal 8 juni 2018, pukul 11.00).

\section{Pasien yang dalam keadaan kurang labil}

Faktor penghambat dalam pemenuhan hak pelayanan adalah beberapa pasien kurang kooperatif, sebagaimana yang di ungkapkan oleh bidang pelayanan dan asuhan keperawatan bapak Yunus Tangebali bahwa Kesulitan yang dilakukan para tenaga medis dalam menghadapi pasien yang kurang labil merupakan faktor penghambat dalam penyembuhan pasien disebabakan mereka kurang disiplin dan taat pada anjuran dari dokter, (Wawancara 7 juni 2018 pukul 10:45).

Faktor-faktor pendukung dapat diketahui bahwa distribusi presentase jawaban responden 
yang menjawab sangat baik $30 \%$, baik $56,7 \%$, kurang baik $10 \%$ dan tidak baik 3,3\% adalah pada aspek perhatian/empati, yang mengungkap mengenai perhatian dokter dan tenaga medis lainnya dalam memberi pelayanan medis kepada pasien yang ditunjang oleh sikap keramahan, kesopanan dan cara perawat melihat kondisi pasien setiap waktu.

Faktor penghambat adalah dapat diketahui bahwa distribusi presentase jawaban responden yang menjawab Responden yang menjawab sangat baik $26,7 \%$, responden yang menjawab baik $40 \%$, responden yang menjawab kurang baik $23,3 \%$, dan responden yang menjawab tidak baik $10 \%$ yang meliputi Tangibles (tampilan/buktifisik)

\section{Upaya pemerintah dalam pemenuhan}

\section{hak pelayanan kesehatan}

Berdasarkan hasil wawancara dalam upaya pemerintah dalam pemenuhan hak pelayanan kesehatan di Rumah Sakit Lakipadada:

\section{a. Menyiapkan tenaga ahli}

Keberhasilan suatu pelayanan kesehatan dalam masyarakat dengan adanya sumber daya manusia yang berkualitas. Sebagaimana Eliaser Toding Mendila, sebagai seksi keperawatan mengungkapkan bahwa Pemerintah Tana Toraja terus mengupayakan penggembangan pemenuhan pelayanan kesehatan bagi masyarakat dengan menyiapkan tenaga ahli yang kompeten dibidangnya terutama bidang kesehatan. Ditandai pada tanggal 12 Februari 2018 pemerintah membuka lowongan tenaga perawat yang berjumlah 137 sesuai keputusan SK yang ditandatangani oleh bupati Tana Toraja dan upaya lain yang dilakukan oleh Pemerintah juga adalah terus mengupayakan dalam penambahan dokter terutama Dokter spesialis. (Wawancara 8 juni 2018 pukul 10:45).

\section{b. Terpenuhinya kesejateraan para tenaga kesehatan}

Terwujudnya pemenuhan pelayanan kesehatan apabila pemerintah memberikan bentuk apresiasi kepada para tenaga medis.Sebagaimana Yunus Tangebali sebagai bidang pelayanan dan asuhan keperawatan mengungkapkan bahwa beberapa upaya yang dilakukan pemerintah dalam meningkatkan kinerja para tenaga medis melalui meningkatkan kesejatraan para tenaga kesehatan dengan membayarkan honor atau gaji tepat waktu dan membayar tunjangantunjangan lainnya ( Wawancara 8 juni 2018 pukul 12.00).

\section{c. Mengadakan kegiatan pelatihan bagi tenaga medis}

Pemerintah Tana Toraja dalam memenuhi hak pelayanan kesehatan bagi masyarakat melalui tenaga kesehatan yang kompeten dan memiliki pengetahuan dalam menjelaskan penyebab penyakit yang diderita oleh pasien, Sebagaimana Eliaser Toding Mendila, seksi keperawatan mengungkapkan bahwa usaha pemerintahan dalam meningkatkan elektabilitas kinerja para tenaga medis yaitu melakukan pelatihan, diklat, dan melakukan kerja sama dengan Fakultas Kedokteran UNHAS ditandai dengan Memorandum of understanding dengan tema Pembangunan Kesehatan di Tana Toraja.

\section{Pembahasan}

1. Penerapan Model Pelayanan pemenuhan Hak Pelayanan kesehatan bagi masyarakat Pelayanan Kesehatan Berdasarkan Aspek Reliability (realibilitas), Assurance (jaminan), Tangibles (tampilan/bukti fisik), Emphaty(empati), Responsiveness (ketangga-pan dan kepedulian).

Rumah sakit Lakipadada kabupaten Tana Toraja adalah merupakan sarana untuk mendapatkan pemenuhan hak pelayanan kesehatan bagi masyarakat. Kesehatan merupakan aspek yang sangat penting dalam kehidupan manusia serta menjadi hak asasi bagi setiap orang seperti ang tercantum dalam Undang-undang Republik Indonesia Nomor 39 Tahun 2009 tentang kesehatan menyatakan bahwa kesehatan merupakan hak asasi manusia dan salah satu unsur kesejahtraan yang harus diwujudkan sesuai dengan cita-cita bangsa Indonesia sebagaimana dimaksud dalam Pancasila dan Undang-Undang Dasar 1945.

Meningkatkan derajat kesehatan masyarakat, banyak hal yang diperhatikan. Salah satunya menyelenggarakan pelayanan kesehatan yang berkualitas yang tujuan utamanya adalah promotif (memelihara dan meningkatkan kesehatan), preventif (pencegahan), kuratif (penyembuhan), dan rehabilitasi (pemulihan) kesehatan perorangan, keluarga, kelompok atau masyarakat, lingkungan, Soekidjo Notoatmodjo (2007:98).

Setiap orang atau pasien dapat memperoleh kegiatan pelayanan kesehatan secara professional, aman, bermutu, anti diskriminasi dan efektif serta lebih mendahulukan pertolongan keselamatan nyawa pasien dibanding kepentingan lainnya.Untuk 
meningkatkan pelayanan kesehatan dibutuhkan tenaga kesehatan yang baik, terampil dan fasilitas rumah sakit yang baik, tetapi tidak semua institusi pelayanan medis tersebut memenuhi kriteria tersebut, sehingga meningkatkan kerumitan sistem pelayanan kesehatan dewasa ini.

Berdasarkan hasil observasi dan wawancara maka pelaksanaan model pelayanan kesehatan di Rumah Sakit Lakipadada kabupaten Tana Toraja didasarkan pada model Serqual (Service quality), teori untuk mengukur tentang pelayanan kesehatan berkualitas dikembangkan Zeithalm dan Parasuraman yang digunakan juga sebagai landasan konsep penelitian yaitu dikenal dengan dimensi RATER. Lima dimensi kualitas pelayanan Kesehatan tersebut mencakup :

a) Reliability (realibilitas) adalah kemampuan untuk memberikan pelayanan yang sesuai dengan janji yang ditawarkan. Penilaian akan kualitas pelayanan dilihat dari kemampuan rumah sakit Lakipadada yang berkaitan dengan ketetapan waktu layanan, ketetapan waktu pendaftaran di loket, ketetapan waktu pemeriksaan dokter, ketetapan dalam proses asuhan keperawatan, lama waktu pemeriksaan dokter dan tenaga keperawatan, tujuan agar pasien atau masyarakat mengetahui waktu yang ditetapkan pihak Rumah Sakit Lakipadada untuk melakukan pelayanan kesehatan.

Penilaian hasil kuesioner aspek reliability(realibilitas) pada pemenuhan hak pelayanan kesehatan bagi masyarakat dari 30 responden yang memberikan jawaban sangat baik (SB) $30 \%$, responden yang menjawab baik (B) $50 \%$, responden yang menjawab kurang baik (KB) 13,3\%, dan responden yang menjawab tidak baik (TB) $6,7 \%$.

b) Assurance (jaminan), kemampuan Rumah Sakit dalam memberikan jaminankesehatan, keterampilan juga memberikankeamanan dalam tindakan tenaga medis sehingga menanamkankepercayaan pasien dan masyarakat terhadap rumah sakit Lakipadada, yang indikatornya terdiri atas keamanan selama perawatan (Patient safety), keamanan barang bawaan pasien dan keluarga, penjelasan protocol asuhan keperawatan, pengetahuan tenaga medis dan perawatan dalam menerangkan efek tindakan medis yang akan dilakukan dan upaya yang dapat dilakukan pasien agar cepat sembuh,memiliki standar pelayanan yang jelas. Penilaian hasil kuesioner aspek assurance(jaminan) pada pemenuhan hak pelayanan kesehatan bagi masyarakat dari 30 responden sangat baik (SB) $26,7 \%$, responden yang menjawab baik (B) $40 \%$, responden yang mejawab kurang baik (KB) $23,3 \%$, responden yang menjawab tidak baik (TB) $10 \%$.

c) Tangibles (tampilan/bukti fisik), adalah wujud kenyataansecarafisik dalam penyelenggaraan kesehatan di rumah sakit lakipadada kepada masyarakat guna mendapatkan perawatan dan penyembuhan meliputi yang baik meliputi kemodernan fasilitas dan perlengkapan, keraplah tenaga medis dan keperawatan, kebersihan, keindahan, dan kerapian, kelengkapan fasilitas perawatan, kenyamanan dalam ruang perawatan, kenyamanan dan fasilitas ruang tunggu.

Penilaian hasil kuesioner aspek tangibles(tampilan/bukti fisik) pada pemenuhan hak pelayanan kesehatan bagi masyarakat dari 30 responden,Responden yang memberikan jawaban pada yang menyatakan sangat baik (SB) 23,3\%, reponden yang memberikan jawaban baik (B) 53,3\%, responden yang menjawab kurang baik (KB) 13,3\%, dan responden yang menjawab tidak baik (TB) $10 \%$.

d) Emphaty (empati), yaitu perhatian secara individual yang diberikan oleh pihak-pihak di Rumah Sakit Lakipadada terutama para tenaga medis dalam memberikan pelayanan kesehatan atau kemudahan pasien dalam mengkomunikasikan keluhannya dan bentuk perhatian tenaga medis yaitu melakukan tindakan yang tepat dan sesuai dengan keluhan dari pasien tersebut.

Penilaian hasil kuesioner aspek tangibles (tampilan/bukti fisik) pada pemenuhan hak pelayanan kesehatan bagi masyarakat dari 30 respondenyang menjawab sangat baik (SB) $30 \%$, responden yang menjawab baik (B) $56.7 \%$, responden yang menjawab kurang baik (KB) $10,0 \%$, dan tidak ada yang memberikan jawaban tidak baik (TB) 3,3\%.

5. Responsiveness (ketanggapan), yaitu pelayanan kesehatan Rumah Sakit Lakipadada secara cepat dan tepat atau kesiapan karyawan dalam membantu masyarakat dan memberikan pelayanan yang cepat dan tanggap, yang meliputi kesigapan karyawan dalam melayani pelanggan, kecepatan karyawan dalam menangani transaksi dan penanganan pasien, yang tujuan untuk mengetahui ketanggapan 
tenaga medis terhadap keluhan atau masalah kesehatan pasien.

Aspek Ketanggapan yang merupakan salah satu pendukung pemenuhan hak pelayanan kesehatan bagi masyarakat dapat diketahui bahwa responden yang menjawab sangat baik (SB) 36,7\%, responden yang menjawab baik (B) $53,3 \%$, responden yang menjawab kurang baik (KB) $6,7 \%$, dan yang memberikan jawaban tidak baik (TB)3,3\%.

\section{Faktor Pendukung dan Penghambat dalam Pemenuhan Hak Pelayanan Kesehatan bagi Masyarakat}

Pembangunan kesehatan merupakan suatu usaha pertumbuhan dan perubahan yang berencana dan dilakukan secara sadar oleh bangsa,negara dan pemerintah dalam bidang kesehatan, menuju modernitas dalam rangka meningkatkan kualitas kesehatan bangsa. Dalam pelayanan kesehatan kualitas memegang peranan penting dalam industri jasa. Pelanggan dalam hal ini pasien akan merasa puas jika mereka memperoleh pelayanan yang lebih baik atau sesuai dengan yang diharapkan.

Penyelenggaraan pemenuhan hak pelayanan kesehatan yang berkualitas sesuatu yang ideal yang diharapkan oleh masyarakat luas , begitupun dengan keberhasilan dari Rumah Sakit Umum Daerah (RSUD) Lakipadada Tana Toraja sebagai salah satu fasilitas kesehatan yang berada di Tana Toraja mempunyai potensi yang cukup baik khususnya di wilayah Tana Toraja dan Toraja Utara tentunya dipengaruhi oleh faktor penentu dalam pelaksanaan model pelayanan yang diterapkan.

\section{Upaya pemerintah dalam pemenuhan hak pelayanan kesehatan}

Pemerintah daerah Tana Toraja sebagai pengelolah dari rumah sakit Lakipadada sebagai penyedia layanan pablik dibidang kesehatan bagi masyarakat bertanggung jawab sepenuhnya dalam mendukung pengadaan fasilitas dan peralatan yang ada di rumah sakit sehingga tenaga medis dapat terbantu dalam melakukan tindakan medis yang tepat dan pasien dapat merasakan puas terhadap pelayanan kesehatan yang diberikan.

Hal ini secara tidak langsung dapat meningkatkan pembangunan ekonomi masyarakat. Kovner menyatakan bahwa peran pemerintah ada 3, yaitu (1) regulator, (2) pemberi biaya; dan (3) pelaksana kegiatan..

Rumah sakit sebagai Lembaga pelayan kesehatan adalah bentuk upaya-upaya yang dilakukan pemerintah dalam mendukung pelayanan kesehatan di Rumah Sakit meliputi pemberian Kartu Indonesia Sehat (KIS), baik dari pusat maupun dari daerah, menyiapkan sarana prasarana yang memenuhi,menyiapkan tenaga ahli, terpenuhinya kesejateraan para tenaga kesehatan, mengadakan kegiatan pelatihan bagi tenaga medis,mengadakan bakti sosial bekerjasama dengan rumah sakit lakipadadadidaerah terpencil 1 kali dalam sebulan serta memantau langsung akan pelaksannaan di Rumah Sakit Lakipadada.

\section{SIMPULAN DAN SARAN}

Berdasarkan hasil penelitian dan pembahasan dapat ditarik kesimpulan sebagai berikut: (1) Pelaksanaan model pelayanan kesehatan di Rumah Sakit Lakipadada kabupaten Tana Toraja didasarkan pada model serqual (Service quality), teori untuk mengukur tentang pelayanan kesehatan berkualitas dikembangkan Zeithalm dan Parasuraman yang digunakan juga sebagai landasan konsep penelitian yaitu dikenal dengan dimensi RATER. Lima dimensi kualitas pelayanan Kesehatan yang mengacu pada Reliability(realibilitas), Assurance (jaminan), Tangibles Emphaty(empati), (tampilan/buktifisik), Responsiveness (ketanggapandankepedulian). (2) Faktor yang mempengaruhi pemenuhan hak pelayanan kesehatan di Rumah Sakit Lakipadada terdiri dari faktor pendukung yaitu sarana dan prasarana, tersedia tenaga medis, ketanggapan dan pengetahuan tenaga medis, sertamemiliki Standar Operasional Prosedur yang lengkapfaktor memperhambat pemenuhan hak pelayanan kesehatan di rumah sakit lakipadada yaitu sumber daya manusia, perbaikan gedung yang belum rampung dan penambahan alat kesehatan, pasien yang dalam keadaan kurang labil. (3) Upaya pemerintah dalam pemenuhan hak pelayanan kesehatan yaitu menyiapkan sarana prasarana yang memenuhi,menyiapkan tenaga ahli, terpenuhinya kesejateraan para tenaga kesehatan, mengadakan kegiatan pelatihan bagi tenaga medis,mengadakan bakti sosial bekerjasama dengan rumah sakit lakipadadadidaerah terpencil 1 kali dalam sebulan.

Adapun saran dalam penelitian ini adalah (1) Diharapkan kepada pihak Rumah sakit lakipadada dan pemerintah setempat agar 
senantiasa meningkatkan pelayanan kesehatan guna tercapai pelayanan kesehatan yang berkualitas, khususnya pada penambahan dokter spesialis, perbaikan gedung dan penambahan alat kesehatan; (2) Diharapkan pasien agar dapat mematuhi setiap prosedur yang telah ditentukan untuk tercapainya keselarasan antara tenaga medis dan pihak pasien dalam interaksinya; (3) Diharapkan keterlibatan semua pihak dalam mendukungkeamanan pelayan dan upaya peningkatanprofesionalisme petugas merupakan komponen pokok dari manajemen rumah sakit dalam rangka memenuhi hak pelayanan kesehatan bagi masyarakat.

\section{DAFTAR RUJUKAN}

Arinanto Satya. 2009. Dimensi-Dimensi HakAsasi ManusiaMengurai Hak Ekonomi, Sosial, dan Budaya. RajaGrafindo.Jakarta.

Alfred, Albert Ameln.1991.Kapita Selekta Hukum Kedokteran. Grafikatama Jaya. Jakarta.

Effendi, Masyhur.2007.Hak Asasi Manusia dalam Dimensi dan Dinamika Yuridis,Sosial,Politik. Ghalia Indonesia.Bogor Selatan.

Fais, M Satrianegara.2014.Organisasi dan Manajemen Pelayanan Kesehatan. Salemba Madika. Jakarta Selatan .

Induniasih.2015. Promosi Kesehatan. Pustaka Baru.Yogyakarta

Jimly,Asshiddiqie.2015.Hukum Tata Negara dan Pilar-Pilar demokrasi.

Konstitusi Press. Jakarta

Komalawati,Veronica.1989.Hukum dan Etika dalam Praktek Dokter. Pustaka Sinar Harapan. Jakarta.

Moleong, Lexy J. 2010. Metodologi Penelitian Kualitatif. Remaja Rosdakarya. Bandung

Nuriyanto. 2014.Penyelenggaraan Pelayanan Publik Di Indonesia, Sudahkah Berlandaskan Konsep "Welfare State". 430 Jurnal Konstitusi (Volume 11 Nomor 3).

Retnaningsih,Ekowati.2013. Akses Layanan Kesehatan. Rajagrafindo Persada. Jakarta

Siswati, Sri.2013. Etika dan Hukum Kesehatan dalam perspektif Undang-Undang Kesehatan.Rajagrafindo. Jakarta

Sugiyono. 2010. Memahami Penelitian Kualitatif. Alfabeta. Bandung
Sinambela.2006.Reformasi Pelayanan Publik. Bumi Aksara. Jakarta

Tangkilisan, Heser Nogi S. 2005.Manajemen Publik. PT. Gramedia Widiasarana Jakarta

Todung, Mulya Lubis.1986.Bantuan Hukum dan Kemiskinan Struktural. LP3ES.Jakarta 